\title{
Ergen annelerine Uygulanan Ebeveyn Stresini Yönetme Programı'nın Etkililiği
}

\section{The Effectiveness of Parent Stress Management Program to Mothers with Adolescent Child}

\section{Neslihan ARICI ÖZCAN ${ }^{\star}$}

\section{Reyhan ARSLAN ${ }^{* *}$}

Öz. Bu araştırma, TEOG sınavına hazırlanan ergenlerin annelerine uygulanan Ebeveyn Stresini Yönetme Programı́nın (ESYP) annelerin anne-babalık stres ve ebeveyn mantıkdışı inanç düzeylerine ve ergenlerin anne baba beklentilerine ilişkin stres ve mantıkdışı inanç düzeylerine etkisini inceleyen yarı deneysel bir çalışmadır. Araştırmada Anne-Baba Stres Ölçeği, Anne-Babaların Akılcı Olmayan İnanç Ölçeği, Anne Baba Beklenti Ölçeği ve Ergenlerde Mantıkdışı İnanç Ölçeği kullanılmıştır. Araştırma 16 anne ve 16 ergen üzerinde yürütülmüştür. Deney grubundaki annelere 6 oturumluk ESYP uygulanırken, kontrol grubuna herhangi bir program uygulanmamıştır. Deney grubuna ESYP uygulandıktan sonra her ik gruptaki annelere ve ergenlere son-test ve izleme testi yapılmıştır. Deney grubu ve kontrol grubu arasındaki ön-test, son-test ve izleme testi puanlarının dağılımları arasındaki farka bakılarak programın etkililiği ve kalıcılı̆̆ incelenmiştir. Bulgular, ESYP'nin annelerin ebeveyn stresini, ebeveyn mantıkdışı inanç düzeylerini ve ergenlerin anne baba beklentilerine ilişkin stres ve mantıkdışı inanç düzeylerini azaltmada anlamlı düzeyde etkili olduğunu ve bu etkinin kalıcı olduğunu göstermiştir.

Anahtar Kelimeler: Anne-babalık stresi, anne babaların mantıkdışı inancı, annebaba beklenti, ergenlerde mantıkdışı inanç.

\begin{abstract}
This quasi experimental research investigates the effectiveness of Parent Stress Management Program (PSMP) on parent stress level of mothers, parent irrational beliefs of mothers and on adolescents' stress level related with parent expectations and irrational beliefs level of adolescents preparing for TEOG exam. To collect data, Parent Stress Scale, Parent Irrational Belief Scale, Parent Expectation Scale and Irrational Beliefs Scale for Adolescents were used. In the study, 16 mothers and 16 adolescents were included. A six session PSMP was applied to mothers in the experimental group; but not in the control group. After the ESYP was applied to the experimental group, posttest and follow-up tests were performed on the mothers and adolescents in both groups. The effectiveness and persistence of the program were examined by looking at the difference between the pre-test, post-test and follow-up test scores between the experimental group and the control group. Results showed that PSMP was significantly effective in decreasing mothers' parent stress and parent irrational beliefs and in decreasing adolescents' parent expectation and irrational beliefs. Also, this effect was found to be persistent after the program.
\end{abstract}

Keywords: Parent stress, parent's irrational beliefs, academic expectation stress, adolescent's irrational beliefs.

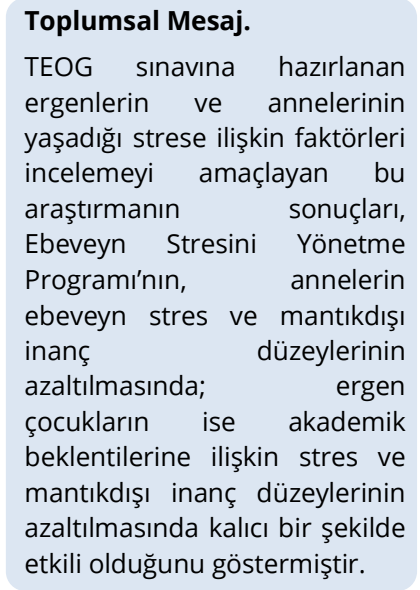

Public Interest Statement.

The study that aims to investigate the factors associated with the stress level of adolescents and their mothers showed that Parent Stress Management Program" is persistently effective in decreasing mothers' parent stress and parent irrational beliefs of mothers; also in adolescents' stress level related with parent expectations and irrational beliefs level of adolescents.

\footnotetext{
* Dr. Öğr. Üyesi, İstanbul Medeniyet Üniversitesi, Sağlık Bilimleri Fakültesi, Sosyal Hizmet Bölümü, Sosyal Hizmetler Anabilim Dalı, neslihan.ozcan@medeniyet.edu.tr

** Arş. Gör., İstanbul Medipol Üniversitesi, Eğitim Fakültesi, Rehberlik ve Psikolojik Danışmanlık Bölümü, reyhanarslan@medipol.edu.tr
} 


\section{GíRiş}

Anne-baba olma, diğer rollere göre daha stresli bir deneyimdir (Creasey ve Reese, 1996). Bu stresli deneyim günümüzde küreselleşme ve teknolojik gelişimlerin beraberinde getirdiği hızlı değişim ile birlikte daha da zorlaşmaktadır (Arkan ve Üstün, 2010). Bu değişimler anne-babaya daha çok sorumluluk yüklemekte ve beraberinde anne-babada stres oluşturabilmektedir (Koeske ve Koeske, 1990). Literatürde ebeveynin beklenilen anne baba olma rolünü (bilgili olma, kısa vadede ve uzun vadede yetkin olma) karşılayamadığını düşündüğünde oluşan strese "ebeveynlik/anne-babalık stresi" denilmektedir (Abidin, 1995; Deater-Deckard, 1998). Ebeveynlik stresi çoklu etkenlerle açıklanabilmektedir (Abidin, 1995; Östberg ve Hagekull, 2000). Yaşama ait kaynakları az olan, sosyoekonomik seviyesi düşük olan ve bir ebeveyn olarak kendini yetkin görme düzeyi düşük olan ebeveynlerin daha çok ebeveynlik stresi yaşadığı bilinmektedir (Aber, Jones ve Cohen, 2000; Duncan ve Brooks-Gunn, 2000). Ayrıca ebeveynlerin ergen bir çocuklarının olması ve çok çocuklu olmaları da ebeveynlik stresini artırmaktadır (Östberg, Hagekull ve Wettergren, 1997; Pearson ve Chan, 1993).

Ebeveynlik stres düzeyinin yüksek olması, ebeveynin bu stresi bilişsel olarak olumsuz yorumlaması ile de ilişkilidir (Bugental ve Johnston, 2000; Deater-Deckard, 1998; Joyce, 1995). Ebeveynlik stres düzeyi yüksek olan ebeveynlerin mantıkdışı inanç düzeyleri de yüksek olmaktadır. Ayrıca bu ebeveynlerin hem kendinden hem çocuklarından gerçekçi olmayan beklentileri de yüksektir (Bugenthal ve Johnston, 2000; DiGiuseppe ve Kelter, 2006; Terjesen ve Kurasaki, 2009). Sonuçta bu tür ebeveynlere sahip olan çocukların çeşitli ruhsal sorunlar (kaygı, depresyon vb.) yaşama ihtimali daha yüksektir (Azar, Megan ve Goslin, 2008; Morgan, Robinson, Aldridge, 2002). Öte yandan anne, çocukla daha yakın ilişki içinde olduğundan annenin ebeveynlik stresi ve mantıkdışı inançları çocuğun psikolojik durumunu daha çok etkileyebilmektedir (Azar ve diğerleri, 2008; Sigel ve McGillicuddy-De Lisi, 2002). Annenin ebeveynlik stres düzeyi ile çocuğunun stres düzeyi genellikle birbirine yakın olmaktadır. Annenin çocuğundan mantıkdışı beklentileri hangi konuda ise çocukta da o konu ile ilgili sorunlar görülmektedir (Bernard, 2003). Örneğin; anne, çocuğunu akademik anlamda yetersiz gördüğünde, çocuk akademik anlamda sorun yaşayabilmektedir (Frome ve Eccles, 1998).

Temel Öğretimden Ortaöğretime Geçiş Sınavı, Türkiye'de ilköğretim düzeyinde yer alan ergenlerin ve ailelerinin yaşamlarını ve psikolojik durumlarını etkileyen önemli bir sınavdır (Yerlikaya, 2014; Zayimoglu-Öztürk ve Aksoy, 2014). Her yıl TEOG sınavına yaklaşık 1 milyon öğrenci hazırlanmaktadır (MEB, 2015). Bu tür sınavlara hazırlanmak ve beraberindeki okul hayatı, ergenlerin kendilerini sürekli olarak akademik anlamda değerlendirmesine yol açmakta ve ergenlerde başarılı olma baskısı yaratmaktadır (Ang ve Huan, 2006; Ayyash-Abdo, 2002; Denscombe, 2000; Kruger, Wandle ve Struzziero, 2007). TEOG sınavına hazırlanan öğrencilerde sınavla ilgili baskı ve kaygı tespit eden birçok ulusal çalışma (Görmez ve Coşkun, 2015; Kesici ve Aşılıoğlu, 2017; Şad ve Şahiner, 2016; Ulusoy, Pan, Turan, Başken, Akbulut, 2016) mevcuttur. Bu durumda Türkiye'de her yıl 1 milyon öğrenci risk grubunda yer almaktadır.

Literatürde akademik baskının ebeveynlerin ve öğretmenlerin beklentileri ile oluştuğu, hatta ebeveynlerin akademik beklentileri ile ergenlerin akademik beklentileri arasında yüksek düzeyde anlamlı bir ilişki olduğu vurgulanmaktadır (Görmez ve Coşkun, 2015; Kaplan, Liu, Kaplan, 2001; Moulds, 2003; Tan ve Yates, 2011; Şad ve Şahiner, 2016; Yıldırım, 2004). Özellikle sosyal statü olarak yükselmek için akademik başarıyı tek seçenek olarak gören Asya ülkelerinde bu stres daha da artmaktadır (Gloria ve Ho, 2003; Tan ve Yates, 2011). Türkiye hem gelişmekte olan bir ülke olduğundan hem de Orta Asya kültürünün özelliklerini barındırdığından, eğitim düzeyinin Türkiye'de bir sınıf değiştirme aracı olarak görüldüğü söylenebilir. Artan akademik beklenti, ergenlerin yaşadığı stres düzeyini artırarak, sınav kaygısı (McDonald, 2001), genel kaygı (Cornell, Krosnick ve Chang, 2006), depresyon (Ang ve Huan, 2006; Cornell ve diğerleri, 2006) gibi birçok ruhsal sorun yaşamalarına yol açmaktadır. Akademik beklenti stresini oluşturan temel etmenlerden biri ise ergenlerin olayları olumsuz yorumlamasına sebep olan mantıkdışı inançlarıdır 
(Putwain, Connors ve Synnes, 2010; Ross, Niebling ve Heckert, 1999). Ergenlikteki mantıkdışı inançların çoğu anne-babanın sahip olduğu mantıkdışı inançlardan edinilmektedir (Azar, 1996; Sigel ve McGillicuddy-De Lisi, 2002). Bu yüzden ergenlerin akademik beklenti streslerini ve mantıkdışı inançlarını azaltmak için ebeveynlerinin beklentilerini ve mantıkdışı inançlarını azaltmak önem taşımaktadır. Ebeveyne uygulanan programların içeriği hem ebeveyni hem de çocuğu kapsadığından sadece çocuklara uygulanan programlardan daha etkilidir (Capaldi, DeGarmo, Patterson ve Forgatch, 2002; DeGarmo, Patterson ve Forgatch, 2004; Gravita ve Joyce, 2008; Lundahl, Risser ve Lovejoy, 2003; Sanders, 2008; Sanders, Bor ve Morawska, 2007).

Uluslararası literatürde ebeveynlik stres düzeyini [The Triple P-Positive Parenting Program (Sanders, 1999), Family and School Together Program -FAST (Kratochwill, McDonald, Levin, BearTibbetts, Demaray, 2004; McDonald, FitzRoy, Fuchs, Fooken ve Klasen 2012), Multidimensional Family Prevention Program (Liddle ve Hogue, 2000)] ve ebeveyn mantıkdışı inançlarını [Friends (Barrett, Shortt, Fox ve Wescombe, 2001; Barrett, Farrell, Ollendick ve Dadds, 2006)] etkin bir şekilde ele alan hem aile terapisi hem de bilişsel davranışçı terapi tabanlı programlar mevcuttur. Öte yandan, bu programlarda daha çok kaygı (Barrett ve Pahl, 2006; Barrett ve diğerleri, 2001; Lowry-Webster, Barrett ve Dadds, 2001), depresyon (Lock ve Barrett, 2003), davranım bozukluğu (The Conduct Problems Prevention Research Group, 2002; Liddle, Singer ve Leckrone, 2005) sorunları ele alınmıştır. Özellikle ebeveynlik stresi ve akademik beklentiye ilişkin stresi ele alan etkin ve sistemik aile terapisi tabanlı grup programları (Fisher, 2003; Kratochwill ve diğerleri, 2004) çok az sayıdadır. Bu tür programlarda aileler sorunlarını paylaşmakta ve eğitici etkinliklerle ailelere problem çözme becerileri kazandırılmaktadır. Benzer şekilde, ebeveyn mantıkdışı inançları ele alan bilişsel davranışçı terapi tabanlı programlar -az sayıda da olsa- mevcuttur (Azar, 1996; Barmish ve Kendall, 2005; Gavita ve Joyce, 1995; 2006). Bu programlarda ise bilişsel yeniden yapılandırma, problem çözme becerileri, psiko-eğitim yer almaktadır (Azar, 1996; Gavita ve Joyce, 2008; Joyce, 1995, 2006).

Ulusal alanyazında ise ebeveynlik stres düzeyini (Çekiç, Akbaş ve Hamamcı, 2015; Özmen ve Özmen, 2008), ebeveyn mantıkdışı inançlarını (Eryüksel ve Agün, 2003; Kaya ve Hamamcı, 2011), ergenlerin akademik beklentilerine ilişkin stresini (Çelik, 2006; Kelecioğlu ve Bilge, 2008) ve ergenlerin mantıkdışı inançlarını (Boyacıoğlu, 2010; Boyacıoğlu ve Küçük, 2011; Çivitçi, 2006a, 2007; Güler, 2012) ayrı ayrı ele alan betimsel çalışmalar vardır. Ayrıca akademik beklentilere ilişkin stresi ve mantıkdışı inançları birlikte ele alan az sayıda betimsel çalışma da (Daymaz, 2012; Zeytin, 2015) bulunmaktadır. Ancak ebeveynlik stres düzeyini ve mantıkdışı inançlarını ele alan sadece bir yarı deneysel çalışma (Çekiç, Akbaş ve Hamamcı, 2016) vardır.

Son olarak hem uluslararası hem de ulusal alanyazında hem annelerin ebeveynlik stres ve mantıkdışı inanç düzeylerini hem de ergenlerin akademik beklentilere ilişkin stres ve mantıkdışı inanç düzeylerini birlikte ele alan deneysel bir programa rastlanmamaktadır. Bu yüzden bu çalışmada, ESYP ile annelerin anne-baba stres ve mantıkdışı inanç düzeyleri ve ergenlerin akademik beklentilere ilişkin stres ve mantıkdışı inanç düzeyleri ele alınmaktadır.

\subsection{Amaç}

Bu çalışma, TEOG sınavına hazırlanan 8. sınıf düzeyindeki ergenlerin annelerine uygulanan "Ebeveyn Stresini Yönetme Programı"nın annelerin anne-baba stres ve mantıkdışı inanç düzeylerine ve ergenlerin akademik beklentilere ilişkin stres ve mantıkdışı inanç düzeylerine etkisini yarı deneysel bir çalışma deseni ile ele almaktır.

\subsection{Hipotezler}

H1: Ebeveyn Stresini Yönetme Programı ebeveynlik stres düzeylerini anlamlı düzeyde azaltmada etkili olacaktır ve bu etki, programın tamamlanmasından bir buçuk ay sonra yapılacak ölçümlerde de devam edecektir. 
H2: Ebeveyn Stresini Yönetme Programı ebeveyn mantıkdışı inanç düzeylerini anlamlı düzeyde azaltmada etkili olacaktır ve bu etki, programın tamamlanmasından bir buçuk ay sonra yapılacak ölçümlerde de devam edecektir.

H3: Ebeveyn Stresini Yönetme Programı ergenlerin anne baba beklentilerine ilişkin stres düzeylerini anlamlı düzeyde azaltmada etkili olacaktır ve bu etki, programın tamamlanmasından bir buçuk ay sonra yapılacak ölçümlerde de devam edecektir.

H4: Ebeveyn Stresini Yönetme Programı ergenlerin mantıkdışı inanç düzeylerini anlamlı düzeyde azaltmada etkili olacaktır ve bu etki, programın tamamlanmasından bir buçuk ay sonra yapılacak ölçümlerde de devam edecektir.

\section{YÖNTEM}

\subsection{Araştırmanın Deseni}

Bu araştırma, 8. sınıf düzeyindeki ergenlerin annelerine uygulanan Ebeveyn Stresini Yönetme Programı́nın annelerin anne-baba stres ve mantıkdışı inanç düzeylerine ve ergenlerin akademik beklentilere ilişkin stres ve mantıkdışı inanç düzeylerine etkisini ortaya koymaya çalışan yarı deneysel bir çalışmadır. Araştırmada ön-test, son-test ve izleme testi ölçümü alınarak, deney ve kontrol gruplu 2x3'lük split-pot, faktöryel (karışık) desen kullanılmıştır (Büyüköztürk, 2002).

Tablo 1. Araştırmanın Deseni

\begin{tabular}{|c|c|c|c|c|}
\hline Gruplar & Ön test & İşlem & Son test & İzleme \\
\hline \multirow[t]{2}{*}{ Deney } & Anne: ABSÖ-ABADÖ & ESYP & Anne: ABSÖ-ABADÖ & $\begin{array}{l}\text { Anne: ABSÖ- } \\
\text { ABADÖ }\end{array}$ \\
\hline & Ergen: ABBÖ-EMiÖ & & Ergen: ABBÖ-EMIÖ & Ergen ABBÖ-EMIÖ \\
\hline \multirow[t]{2}{*}{ Kontrol } & Anne: ABSÖ-ABADÖ & İşlem Yok & Anne: ABSÖ-ABADÖ & $\begin{array}{l}\text { Anne: ABSÖ- } \\
\text { ABADÖ }\end{array}$ \\
\hline & Ergen: ABBÖ-EMIÖ & & Ergen: ABBÖ-EMIÖ & Ergen: ABBÖ-EMIÖ \\
\hline
\end{tabular}

ABSÖ: Anne-Baba Stres Ölçeği; ABADÖ: Anne-Baba Akıldışı İnanç Ölçeği; ABBÖ: Anne-Baba Beklenti Ölçeği; EMiÖ: Ergen Mantıkdışı İnanç Ölçeği

\section{2. Çalışma grubu}

Araştırmaya katılacak anneleri ve ergenleri belirlemek amacıyla ilk olarak araştırmacı tarafından uygun örneklem yöntemi ile İstanbul'da dezavantajlı ailelerin (sosyo-ekonomik ve eğitim seviyesi düşük) ikamet ettiği bir semt seçilmiştir. İkinci olarak da bu semtte belediyenin bilgi evinden TEOG sınavı için eğitim desteği alan ve 8. sınıf düzeyinde çocuğu olan aileler belirlenmiştir. Araştırma süreci, Ocak 2016-Nisan 2016 tarihleri arasında İstanbul Belediyesi Kütüphane Daire Başkanlığına bağı bilgi evinden destek alan ailelerden izin alınarak yürütülmüştür. Bilgi evinde TEOG sınavı için destek alan, 8. sınıf düzeyinde 124 ergene ve annesine ulaşılmıştır. Ulaşılan 124 anneye ABSÖ (Kaymak-Özmen ve Özmen, 2012) ve ABADÖ (Kaya ve Hamamcı, 2011); 8. sınıfa giden 124 ergene de ABBÖ (Çelik, 2006) ve EMiÖ (Çivitçi, 2006a) uygulanmıştır. Uygulama sonucunda annelere verilen $A B S O ̈$ ve ABADÖ ölçeklerinden ortalamanın yarım standart sapma üstünde olan (Xort $=42.35$, Ss=10.91), $(X=108.08, \mathrm{Ss}=15.44) 34$ kişi araştırmaya katılmak için belirlenmiştir. Ayrıca ergenlere verilen ABBÖ ve EMiÖ ölçeklerinin her ikisinden de ortalamanın yarım standart sapma üstünde olan (Xort $=34.24, \mathrm{Ss}=5.67),(X o r t=72, \mathrm{Ss}=11,36) 38$ kişi araştırmaya katılmak için belirlenmiştir. Belirlenen 34 anne ve 38 ergenden anne-çocuk olarak eşleşen 24 katılımc tespit edilmiştir. Bu 24 katılımcıdan ise 16 katılımcı araştırmaya katılmaya gönüllü olmuş ve deney ve kontrol grubuna seçkisiz yöntemle yerleştirilmiştir. Deney ve kontrol grubunda yer alan katılımcıların demografik özelliklerine ait bilgiler Tablo 2'de verilmiştir. 
Tablo 2. Deney ve Kontrol Grubunda Yer Alan Katılımcıların Demografik Özellikleri

\begin{tabular}{|c|c|c|c|c|c|c|c|c|c|c|c|c|}
\hline & Yas & Yas & Yas & Eğitim & & & Çocuk & & & Çalışma & & \\
\hline & Aralığı & $\mu$ & $\mathrm{Sd}$ & Durumu & $n$ & $\%$ & Sayısı & $\mathrm{n}$ & $\%$ & Durumu & $\mathrm{n}$ & $\%$ \\
\hline \multicolumn{13}{|l|}{ Deney } \\
\hline \multirow[t]{2}{*}{ Grubu } & $35-45$ & 41.2 & 3.35 & ìlkokul & 5 & 62.5 & 2 & 4 & 50 & Çalışmayan & 7 & 87.5 \\
\hline & & & & Ortaokul & 3 & 37.5 & $3 \geq$ & 4 & 50 & Çalışmayan & 1 & 12.5 \\
\hline \multicolumn{13}{|l|}{ Kontrol } \\
\hline \multirow[t]{2}{*}{ Grubu } & $32-43$ & 40.6 & 4.26 & ìlkokul & 6 & 75 & 2 & 5 & 62.5 & Çalışamayan & 6 & 75 \\
\hline & & & & Ortaokul & 2 & 25 & $3 \geq$ & 3 & 50 & Çalışan & 2 & 25 \\
\hline
\end{tabular}

\subsection{Veri Toplama Araçları}

Anne-Baba Stres Ölçeği (ABSÖ): Kaymak-Özmen ve Özmen tarafından (2012) geliştirilmiştir. Anne babaların günlük yaşamda çocukları ile ilişkilerinde yaşadığı stresi ölçmektedir. 16 maddelik, 4 Likertli bir öz-bildirim ölçeğidir. Açımlayıcı faktör analizi sonucunda varyansın \%32.20'sini açıklamıştır, tek boyutludur. Bu tek boyutlu yapının doğrulayıcı faktör analizinde de model veri uyumu iyi düzeydedir $\left(\chi^{2}=252.98(N=438, s d=104, p=.000), \chi^{2} / s d=252.98 / 104=2.43\right.$, RMSEA=0.05, $\mathrm{RMR}=0.03, \mathrm{RMS}=0.04, \mathrm{GFI}=0.93, \mathrm{AGFI}=0.91, \mathrm{CFI}=0.91)$. Ölçeğin Cronbach Alfa iç tutarlılık katsayısı .85 'tir. Madde toplam korelasyonları ise .34 ile .58 arasında değişmektedir. Bu çalışma grubunda ölçeğin Cronbach Alfa iç tutarlılık katsayısı .87 olarak bulunmuştur.

Anne-Baba Akıl Dışı Inançlar Ölçeği (ABADÖ): Kaya ve Hamamcı (2011) tarafından geliştirilmiştir. Anne babaların mantıkdışı inançlarını değerlendirilmeye yönelik bir ölçektir. 29 maddelik, 5 Likertli bir özbildirim ölçeğidir. Yapılan faktör analizi sonucunda, "beklentiler" ve "mükemmeliyetçilik" olmak üzere iki alt boyutu olduğu saptanmıştır. Ölçeğin Cronbach Alfa iç tutarlılık katsayısı ise .86 olarak belirlenmiştir. Bu çalışma grubunda da ölçeğin Cronbach Alfa iç tutarlılık katsayısı .86 olarak bulunmuştur.

Anne Baba Beklenti Ölçeği (ABBÖ): Huang (1996) tarafından geliştirilmiş olan ölçek, Çelik (2006) tarafından Türkçe'ye uyarlanmıştır. Çocuğun akademik anlamda algıladığı anne-baba beklentisini ölçen, 22 maddelik, 3 Likertli ve dört alt boyutlu (anne babanın çocuktan en iyisini yapma beklentisi, anne-babanın mükemmel öğrenci beklentisi, anne babanın çok çalışma beklentisi ve anne babanın notlarla ilgili beklentileri) bir öz-bildirim ölçeğidir. Cronbach Alfa iç tutarlılık katsayısı .78'dir. Bu çalışma grubunda ölçeğin Cronbach Alfa iç tutarlılık katsayısı .82 olarak bulunmuştur.

Ergen Mantıkdışı Inançlar Ölçeği (EMiö): Çivitçi (2006a) tarafından geliştirilmiştir. Öğrencilerin mantıkdışı inanç düzeylerini belirlemeyi amaçlamaktadır. EMiö, 3 alt boyuttan (başarı talebi, saygı talebi, rahatlık talebi) oluşan, 21 maddelik 5 Likertli bir öz-bildirim ölçeğidir. EMiö’nün yapı geçerliği çalışmasında faktör yüklerinin .69 ile .40 arasında değiştiği ve toplam varyansın \%33'ünü açıklayan üç faktör elde edildiği görülmüştür. Ölçeğin Cronbach Alfa iç tutarlık katsayıları toplam puan için .71 , başarı talebi alt ölçeği için .62, rahatlık talebi alt ölçeği için .61 ve saygı talebi alt ölçeği için .57'dir. Bu çalışma grubunda tüm ölçek için Cronbach Alfa iç tutarlılık katsayısı .76'dır.

Kişisel Bilgi Formu: Katılımcılara ait kişisel ve aileye ilişkin bilgiler, araştırmacı tarafından geliştirilen kişisel bilgi formu kullanılarak elde edilmiştir.

\subsection{Deneysel işlem}

\subsubsection{Ebeveyn Stresini Yönetme Programı'nın Kapsamı}

ESYP, araştırmacı tarafından geliştiren, annelerin anne-babalık stres ve mantıkdışı inanç düzeylerini ve ergenlerin akademik beklentilere ilişkin stres ve mantıkdışı inanç düzeylerini azaltmaya yönelik psikolojik bir müdahale programıdır. ESYP'nin geliştirilme aşamasında, ebeveynlik stres, ebeveyn mantıkdışı inanç, anne-baba beklentilere ilişkin stres ve ergen mantıkdışı inanç kavramlarına yönelik kuramsal bilgiler, uygulamalar ve programlar incelenmiştir (FRIENDS: Barrett ve diğerleri 
2006; FAST: Kratochwill ve diğerleri, 2004; McDonald ve diğerleri, 2012; The Triple P-Positive Parenting Program: Sanders,1999). Bu programların bazıları bilişsel davranış̧̧ı terapi tabanlı (FRIENDS: Barrett ve diğerleri 2006) iken, bazıları sistemik aile terapisi tabanlıdır (FAST: Kratochwill ve diğerleri, 2004; McDonald ve diğerleri, 2012; Üçlü P - Pozitif Ebeveyn Programı /The Triple PPositive Parenting Program: Sanders,1999). Bu nedenle mevcut çalışmadaki program ve teknikler bilişsel davranışçı terapi (davranışsal tekniklerden: rahatlama ve gevşeme egzersizleri; bilişsel davranışçı kuramın tekniklerinden: irrasyonel düşünceyi tespit etme) ve sistemik aile terapisi (fotoğraflarla çalışma) temel alınarak hazırlanmıştır.

\subsubsection{Ebeveyn Stresini Yönetme Programı'nın İçeriği}

ESYP, 6 oturumluk bir psikolojik müdahale grup programıdır. Oturumlarda ebeveynlik stres, ebeveyn mantıkdışı inanç, anne-baba beklentilerine ilişkin stres ve ergen mantıkdışı inanç kavramlarına yönelik 18 etkinliğe yer verilmiştir. Her oturumda toplam üç etkinlik yer almaktadır ve etkinliklerin ortalama süresi 20- 25 dakikadır. Oturumlardaki ilk etkinlik ısınmaya, ikinci etkinlik oturumun esas amacına, üçüncü etkinlik ise oturumdan olumlu duygularla ayrılmaya yöneliktir. Isınmaya yönelik etkinliklerden bir tanesi "Kazanım Çarkım" etkinliğidir. Bu etkinlikte katılımcıya yaşanılan her olayda bir kazanım olduğunu ve bu kazanımların onlara yaşamda kaynak olduğunu fark ettirmek amaçlanmıştır. Programın amacına yönelik olan etkinliklerden bir diğeri de "Beklenti Çadırı" etkinliğidir. Bu etkinlikte ebeveynin çocuğundan beklentisi ve çocuğun ebeveyninden beklentisi ele alınmakta ve sorgulanmaktadır. Oturumdan olumlu duygularla ayrılmaya yönelik etkinliklerden bir tanesi ise "Konteynır" etkinliğidir. Bu etkinlikte amaç, katılımcıya olumsuz düşünceler geldiğinde bu olumsuz düşüncelerle nasıl başa çıkacağını göstermektir. Oturumlarda ele alınan konular Tablo 6'da sunulmuştur.

Tablo 6. Ebeveyn Stresini Yönetme Programı İçeriği

- Tanışma, kaynaşma

1.0turum - Bireyi strese sokan etmenleri (bireysel, ebeveyn, aile) ve beklentilerini tanımlama

- Ebeveyn olarak strese sokan etmenlerin ve beklentilerinin bireysel (fiziksel, duygusal, zihinsel vb) ve ailesel (tartışma vb) etkilerini ele

2. Oturum alma

- Ebeveyn olarak strese sokan etmenlerle nasıl başa çıktıklarını fark ettirme

- Ebeveyn stresi karşısında hissedilen duyguları ve bedensel tepkileri

3. Oturum ele alma

- Ebeveyn stresi ile duygusal ve bedensel başa çıkmayı öğrenme

- Ebeveyn stresinin bireyde oluşturduğu mantıkdışı inançlar ve

4.0turum

5.Oturum

6. Oturum sağlıksız davranışları sorgulama ve ele alma

- Ebeveyn stresinin bireyde oluşturduğu mantıkdışı inançlar ve sağlıksı davranışlar ile bilişsel olarak nasıl başa çıkacaklarını ele alma

- Ebeveyn stresinin bireyde oluşturduğu mantıkdışı inançlar ve sağlıksız davranışlar ile bilişsel olarak nasıl başa çıkacaklarını detaylı öğrenme

- Ebeveyn stresi ile başa çıkmak için bireysel ve ailesel kaynakları ele alma

- Ebeveyn stresini yeniden tanımlama

- Gelecekte ebeveyn olarak strese sokacak etmenler karşısında bireyi ve ailesini hazırlıklı kılma 


\subsubsection{Ebeveyn Stresini Yönetme Programı́nın Kapsamı Uygulama Şekli (Süre-Sıklık- Toplanılan Yer)}

Bu program, İstanbul iı Merkezinde dezavantajlı ailelerin çocuklarına akademik destek veren bilgi evinin toplantı salonunda uygulanmıştır. Oturumlar sırasında üyeler bir daire oluşturacak şekilde oturmuşlardır. Altı oturumluk eğitim programı, altı hafta boyunca haftada bir gün olacak şekilde yürütülmüştür. Her bir oturumun süresi ortalama 90 dakikadır. Oturumda her bir etkinlik yaklaşık 20-25 dakika sürmüştür.

\subsection{Verilerin Analizi}

Araştırmada parametrik testlerin kullanılabilmesi için, varyansların homojen olması ve verilerin normal dağılıma uyması gerekmektedir (Büyüköztürk, 2002). Parametrik testin sonuçları, her iki grupta yer alan deneklerin, ABSÖ ( $\left.F_{1-14}=2.11, p>.05\right)$, ABADÖ ( $\left.F_{1-14}=.756, p>.05\right)$ ABBÖ $\left(F_{1-14}=0.25\right.$, $\mathrm{p}>.05)$ ve EMiÖ $\left(\mathrm{F}_{1-14}=1.04, \mathrm{p}>.05\right)$ ön-test ölçümlerinden aldıkları puanların ortalamaları arasında anlamlı bir fark olmadığını göstermiştir. Homojenlik testinden elde edilen sonuçlara göre gruplar birbirine denktir. Ayrıca Kolmogrov-Smirnov testine göre normal dağılım göstermektedir. Bu bulgular, Tablo 3 ve Tablo 4'ten izlenebilir.

Tablo 3. Deney ve Kontrol Gruplarının Ön-test Puanlarına ait Homojenlik Testi Analiz Sonuçları

\begin{tabular}{lcccc}
\hline Değişken & $\begin{array}{c}\text { Levene } \\
\text { Statistic }\end{array}$ & $\mathrm{df1}$ & $\mathrm{df2}$ & $p$ \\
\hline Ön-test ABSÖ & .411 & 1 & 14 & .532 \\
Ön-test ABADÖ & .061 & 1 & 14 & .809 \\
Ön- test ABBÖ & .581 & 1 & 14 & .459 \\
Ön-test EMiÖ & .003 & 1 & 14 & .959 \\
\hline
\end{tabular}

Tablo 4. Deney ve Kontrol Gruplarının Ön-test Puanlarına ait Kolmogorov-Smirnov Normallik Testi Sonuçları

\begin{tabular}{lccc}
\hline & \multicolumn{3}{c}{ Kolmogorov-Smirnov(a) } \\
\hline Değişken & Statistic & $\mathrm{df}$ & $p$ \\
Ön-test ABSÖ & .750 & 16 & .627 \\
Ön-test ABADÖ & .500 & 16 & .964 \\
Ön- test ABBÖ & .250 & 16 & 1.00 \\
Ön-test EMiÖ & .500 & 16 & .964 \\
\hline
\end{tabular}

Ayrıca deney ve kontrol gruplarının, her dört ölçeğe ilişkin ön-test ölçümlerinden elde ettikleri puanların, çarpıklık (skewness) ve basıklık (kurtosis) düzeyleri de incelenmiştir. Bulgular Tablo 5'te verilmiştir.

Tablo 5. Deney ve Kontrol Gruplarında Bulunan ABSÖ ve ABADÖ ve ABBÖ ve EMiö'den Elde Etikleri Puanlara İlişkin Değerler

\begin{tabular}{llcccccc}
\hline & Grup & $\bar{X}$ & Ss & Ortanca & Mod & Çarpıklık & Basıklık \\
\hline \multirow{2}{*}{ ABSÖ } & Deney & 49.75 & 3.91 & 50 & 50 & -.055 & -186 \\
& Kontrol & 52.87 & 4.64 & 53 & 45 & -.340 & -322 \\
\hline \multirow{2}{*}{ ABADÖ } & Deney & 11.62 & 3.62 & 113.5 & 109 & .308 & -1.153 \\
& Kontrol & 112.12 & 3.27 & 110.5 & 110 & 1.094 & -.179 \\
\hline \multirow{2}{*}{ ABBÖ } & Deney & 37.87 & 1.35 & 38 & 38 & -.165 & -.166 \\
& Kontrol & 37.75 & 1.75 & 38 & 36 & .717 & .267 \\
\hline \multirow{2}{*}{ EMiÖ } & Deney & 78.125 & 1.95 & 78 & 76 & .985 & 1.358 \\
& Kontrol & 78.75 & 1.90 & 78 & 78 & .637 & .155 \\
\hline
\end{tabular}


Yukarıda elde edilen ön analiz bulguları doğrultusunda parametrik testlerin kullanılmasına karar verilmiştir. Ayrıca araştırmada, deney ve kontrol grupları olmak üzere iki grup bulunmaktadır. Ölçümler açısından ise grupların kendi içinde, bireyler arası ve bireyler içi ölçümleri söz konusudur. Ön-test, son-test ve izleme testi ölçümlerindeki değişimlerin istatistiksel anlamlılığını kararlaştırmada kullanılan yollardan biri "tek faktör üzerinde tekrarlanmış ölçümler için ỉki yönlü ANOVA"dır (Balcı, 1997). Yukarıdaki özellikler dikkate alındığında, bu araştırmada kullanılan deneysel desenin split-plot (karışık) desen özelliği gösterdiği görülmektedir. Bu nedenle, split-plot (karışık) desenler için uygun olan, tekrarlanmış ölçümler için 2x3 iki faktörlü ANOVA tekniği kullanılmıştır (Büyüköztürk, 2002). Bu analiz sonucunda, anlamlı farkın gözlendiği durumlarda ise farkın kaynağını test edebilmek için veriler, Tukey (HSD) testi ile analiz edilmiştir.

Araştırma kapsamında ön-test, son-test ve izleme testi ölçümleri sonucunda elde edilen veriler, bilgisayar ortamına aktarımıştır. Araştırmada, bulguların istatistiksel analizleri $p<.05$ anlamlıık düzeyi esas alınarak gerçekleştirilmiş, ayrıca $p<.01$ düzeyleri de belirtilmiştir. Verilerin analizi için SPPS 16.0 paket programı kullanıımıştır.

\section{BULGULAR}

Bu bölümde araştırmanın denencelerini test etmek üzere yapılan istatistiksel analizlere ve bu analizlerden elde edilen bulgulara yer verilmiştir.

\subsection{Anne-Babalık/Ebeveyn Stresini Azaltmaya ilişkin Bulgular}

Araştırmanın birinci denencesi, “Ebeveyn Stresini Yönetme Programı, anne-babalık stres düzeylerini anlamlı düzeyde azaltmada etkili olacaktır ve bu etki programın tamamlanmasından bir buçuk ay sonra yapılacak ölçümlerde de devam edecektir" şeklinde ifade edilmiştir. Deney ve kontrol gruplarında yer alan katıımcıların ABSÖ ön-test, son-test, izleme testi aritmetik ortalamaları ve standart sapmaları Tablo 7'de verilmiştir.

Tablo 7. Deney ve Kontrol Gruplarının ABSÖ Aritmetik Ortalama ve Standart Sapma Değerleri

\begin{tabular}{clcccccc}
\hline & & \multicolumn{2}{c}{ Ön-test } & \multicolumn{2}{c}{ Son-Test } & \multicolumn{2}{c}{ Izleme Testi } \\
& Grup & $\bar{X}$ & ss & $\bar{X}$ & ss & $\bar{X}$ & ss \\
\hline \multirow{2}{*}{ ABSÖ } & Deney & 49.750 & 3.91 & 38.375 & 1.84 & 38.875 & 1.24 \\
& Kontrol & 52.875 & 4.64 & 55.125 & 3.090 & 56.265 & 3.24
\end{tabular}

Tablo 7 incelendiğinde, deney ve kontrol gruplarının ön-test puan ortalamalarının birbirine denk olduğu görülürken; son-test ve izleme testi puanlarında deney grubu ve kontrol grubu arasında farklılıklar olduğu görülmektedir. Deney ve kontrol gruplarının ABSÖ'den elde ettikleri puan ortalamaları arasındaki farkın anlamlı olup olmadığı varyans analizi (ANOVA) ile test edilmiştir. Elde edilen bulgular Tablo 8'de sunulmuştur.

Tablo 8. Deney ve Kontrol Gruplarının ABSÖ Ön-test, Son-test ve İleme Testi Puanlarına iliş̧kin Iki Faktörlü Varyans Analizi Sonuçları

\begin{tabular}{ccccccc}
\hline Kaynak & $\begin{array}{c}\text { Kareler } \\
\text { Toplamı }\end{array}$ & sd & $\begin{array}{c}\text { Kareler } \\
\text { Ortalaması }\end{array}$ & $F$ & $p$ & $\begin{array}{c}\text { Eta } \\
\text { Kare }\end{array}$ \\
\hline Grup (D//K) & 1887.521 & 1 & 1887.521 & 99.110 & .000 & .876 \\
Hata & 266.625 & 14 & 19.045 & & & \\
Gruplar içi & 885.312 & 16 & & & & \\
Ölçüm (ön-son- izleme) & 184.042 & 1 & 1317.638 & 15.406 & .000 & .534 \\
Grup * Ölçüm & 534.02 & 1 & 399.389 & 44.703 & .000 & .762 \\
Hata & 167.250 & 14 & 8.934 & & & \\
\hline
\end{tabular}


Tablo 8'de görüldügü üzere, deney ve kontrol gruplarında bulunan bireylerin, ABSÖ ön-test, sontest ve izleme testi ölçümlerinden aldıkları puanların ortalamaları üzerinde yapılan varyans analizi sonucunda, grup etkisinin anlamlı olduğu bulunmuştur $\left(F_{(1-14)}=99,110 ; p<.01\right)$. Buna göre, deney ve kontrol gruplarının ön-test, son-test ve izleme testi ölçümleri arasında ayrım yapmaksızın, ABSÖ'den elde ettikleri puanların ortalamaları arasında anlamlı düzeyde bir fark bulunduğu söylenebilir. Grup ayrımı yapılmaksızın bireylerin, ön-test, son-test ve izleme testi ölçümlerinden elde ettikleri puanların ortalamaları arasındaki farkın da anlamlı olduğu görülmüştür $\left(F_{(2-14)}=15,406\right.$ $\mathrm{p}<.01)$. Bu bulgu, grup ayrımı yapılmadığında, bireylerin anne-babalık stres düzeylerinin deneysel işleme bağlı olarak değiştiğini göstermektedir. Ayrıca bu araştırma için önemli olan ortak etkinin (grup * ölçüm etkisinin) incelenmesi sonucunda, elde edilen değerin anlamlı olduğu görülmüştür $(F(2-14)=44,73 ; p<.01)$. Bu bulgu, deney ve kontrol gruplarındaki bireylerin ön-test, son-test ve izleme testi ölçümlerinde ABSÖ'den elde ettikleri puanların değiştiğini göstermektedir. Tüm bu bulgular dikkate alındığında, anne-babalık stresi ile ilgili öne sürülen denencenin doğrulandığı söylenebilir. Gruplar arasındaki ölçümlere bağlı olarak, anlamlı farkın hangi gruplar arasında olduğunu belirlemek amacıyla Tukey Testi yapılmıştır.

Tukey testi sonucuna göre, deney grubunun ABSÖ'nün ön-testinden $(X=49.75)$ elde ettikleri puanların ortalamaları ile son-test $(X=38.37)$ ve izleme testi $(X=38.87)$ ölçümlerinden elde ettikleri puanların ortalamaları arasında anlamlı bir fark bulunmaktadır (11.37 ve 10.87; $p<.01$ ). Buna karşın, kontrol grubunun ABSÖ ön-testinden $(X=52.87)$ elde ettikleri puanların ortalamaları ile sontest $(X=5512)$ ve izleme testi $(X=56.26)$ ölçümlerinden elde ettikleri puanların ortalamaları arasındaki fark anlamlı değildir (-.2.25 ve -3.75). Ayrıca deney grubundaki bireylerin son-test $(X=$ 38.37) puanları ile kontrol grubundaki bireylerin son-test $(X=55.12)$ puanları arasında ve deney grubundaki bireylerin izleme testi $(X=38.37)$ ile kontrol grubundaki bireylerin izleme testi $(X=$ 56.26) puanları arasında anlamlı bir farklılık $(-16.75$ ve $-17.75 ; p<.01)$ olduğu görülmektedir. Bu sonuçlar, ESYP'nin anne-babalık stres düzeylerini deney grubunda azaltmada anlamlı düzeyde etkili olduğunu göstermektedir.

\subsection{Anne-Baba Akıldışı İnançları Azaltmaya Yönelik Bulgular}

Araştırmanın ikinci denencesi, “Ebeveyn Stresini Yönetme Programı, ebeveyn akıldışı inanç düzeylerini anlamlı düzeyde azaltmada etkili olacaktır ve bu etki programın tamamlanmasından bir buçuk ay sonra yapılacak ölçümlerde de devam edecektir" şeklinde ifade edilmiştir. Deney ve kontrol gruplarında yer alan katılımcıların ABADÖ ön-test, son-test, izleme testi aritmetik ortalamaları ve standart sapmaları Tablo 9'da verilmiştir.

Tablo 9. Deney ve Kontrol Gruplarının ABADÖ Ön-Test, Son-Test ve İzleme Testi Puanlarına Illişkin Aritmetik Ortalama ve Standart Sapma Değerleri

\begin{tabular}{llcccccc}
\hline & & \multicolumn{2}{c}{ Ön-test } & \multicolumn{2}{c}{ Son-Test } & \multicolumn{2}{c}{ Izleme-Testi } \\
& Grup & $\bar{X}$ & ss & $\bar{X}$ & ss & $\bar{X}$ & ss \\
\hline ABADÖ & Deney & 113.62 & 3.6 & 80.62 & 2.82 & 82.50 & 2.44 \\
& Kontrol & 112.12 & 3.27 & 111.75 & 3.53 & 113.87 & 3.18 \\
\hline
\end{tabular}

Tablo 9 incelendiğinde, deney ve kontrol gruplarının ön-test puan ortalamalarının birbirine denk olduğu görülürken; son-test ve izleme testi puanlarında deney grubu ve kontrol grubu arasında farklılıklar olduğu görülmektedir. Deney ve kontrol gruplarının ABADÖ'den elde ettikleri puan ortalamaları arasındaki farkın anlamlı olup olmadığı varyans analizi (ANOVA) ile test edilmiştir. Elde edilen bulgular Tablo 10'da sunulmuştur. 
Tablo 10. Deney ve Kontrol Gruplarının ABADÖ Ön-test, Son-test ve İzleme Testi Puanlarına ilişkin iki Faktörlü Varyans Analizi Sonuçları

\begin{tabular}{ccccccc}
\hline Kaynak & $\begin{array}{c}\text { Kareler } \\
\text { Toplamı }\end{array}$ & sd & $\begin{array}{c}\text { Kareler } \\
\text { Ortalaması }\end{array}$ & $F$ & $p$ & $\begin{array}{c}\text { Eta } \\
\text { Kare }\end{array}$ \\
\hline Gruplar arası & 5213.917 & 15 & & & & \\
Grup (D//K) & 4920.750 & 1 & 4920.750 & 234.987 & .000 & .944 \\
Hata & 293.167 & 14 & 20.940 & & & \\
Gruplar içi & 5641.083 & 16 & & & & \\
Ölçüm (ön-son- izleme) & 2674.125 & 1 & 1658.158 & 290.591 & .000 & .954 \\
Grup * Ölçüm & 2838.125 & 1 & 1760.006 & 308.439 & .000 & .957 \\
Hata & 128.833 & 14 & 5.706 & & & \\
\hline
\end{tabular}

Tablo 10'da görüldüğü üzere, deney ve kontrol gruplarında bulunan bireylerin, ABADÖ ön-test, sontest ve izleme testi ölçümlerinden aldıkları puanların ortalamaları üzerinde yapılan varyans analizi sonucunda, grup etkisinin anlamlı olduğu bulunmuştur $(F(1-14)=234,987 ; p<.01)$. Buna göre, deney ve kontrol gruplarının ön-test, son-test ve izleme testi ölçümleri arasında ayrım yapmaksızın, ABADÖ'den elde ettikleri puanların ortalamaları arasında anlamlı düzeyde bir fark bulunduğu söylenebilir. Grup ayrımı yapılmaksızın bireylerin, ön-test, son-test ve izleme testi ölçümlerinden elde ettikleri puanların ortalamaları arasındaki farkın da anlamlı olduğu görülmüştür $\left(F_{(2-14)}=\right.$ 290,591 p< .01). Bu bulgu, grup ayrımı yapılmadığında, bireylerin akıldışı inanç düzeylerinin deneysel işleme bağlı olarak değiştiğini göstermektedir. Ayrıca bu araştırma için önemli olan ortak etkinin (grup*ölçüm etkisinin) incelenmesi sonucunda, elde edilen değerin anlamlı olduğu görülmüştür $\left(F_{(2-14)}=44,73 ; p<.01\right)$. Bu bulgu, deney ve kontrol gruplarındaki bireylerin ön-test, sontest ve izleme testi ölçümlerinde ABADÖ'den elde ettikleri puanların değiştiğini göstermektedir. Tüm bu bulgular dikkate alındığında, akıldışı inançla ilgili öne sürülen denencenin doğrulandığı söylenebilir. Gruplar arasındaki ölçümlere bağı olarak, anlamlı farkın hangi gruplar arasında olduğunu belirlemek amacıyla Tukey Testi yapılmıştır.

Tukey testi sonucuna göre, deney grubunun ABADÖ'nün ön-testinden $(X=113.62)$ elde ettikleri puanların ortalamaları ile son-test $(X=80.62)$ ve izleme testi $(X=82.50)$ ölçümlerinden elde ettikleri puanların ortalamaları arasında anlamlı bir fark bulunmaktadır (33 ve 31.1; $p<.01$ ). Buna karşın, kontrol grubunun ABADÖ ön-testinden $(X=112.12)$ elde ettikleri puanların ortalamaları ile son-test $(X=111.75)$ ve izleme testi $(X=112.87)$ ölçümlerinden elde ettikleri puanların ortalamaları arasındaki fark anlamlı değildir (-.35 ve -1.75). Ayrıca deney grubundaki bireylerin son-test $(X=$ 80.62) puanları ile kontrol grubundaki bireylerin son-test $(X=111.75)$ puanları arasında ve deney grubundaki bireylerin izleme testi $(X=82.50)$ ile kontrol grubundaki bireylerin izleme testi $(X=$ 113.87) puanları arasında anlamlı bir farklııı (-31.25 ve $-31.25 ; p<.01)$ olduğu görülmektedir. Bu sonuçlar, ESYP'nin ebeveyn akıldışı inanç düzeylerini deney grubunda azaltmada anlamlı düzeyde etkili olduğunu göstermektedir.

\subsection{Ergenlerde Anne-Baba Beklentisinin Azalmasına Yönelik Bulgular}

Araştırmanın üçüncü denencesi, "Ebeveyn Stresini Yönetme Programı, ergenlerin anne-baba beklenti düzeylerini anlamlı düzeyde azaltmada etkili olacaktır ve bu etki programın tamamlanmasından bir buçuk ay sonra yapılacak ölçümlerde de devam edecektir." şeklinde ifade edilmiştir. Deney ve kontrol gruplarında yer alan katılımcıların ABBÖ ön-test, son-test, izleme testi aritmetik ortalamaları ve standart sapmaları Tablo 11 'de verilmiştir. 
Tablo 11. ABBÖ Anne- Baba Beklenti Ön-Test, Son-Test ve İzleme Testi Puanlarına ilişkin Aritmetik Ortalama ve Standart Sapma Değerleri

\begin{tabular}{llcccccc}
\hline & & \multicolumn{2}{c}{ Ön-test } & \multicolumn{2}{c}{ Son-Test } & \multicolumn{2}{c}{ İleme-Testi } \\
& Grup & $\bar{X}$ & ss & $\bar{X}$ & ss & $\bar{X}$ & ss \\
\hline \multirow{2}{*}{ ABBÖ } & Deney & 37.87 & 1.35 & 27.87 & 1.48 & 27 & 1.51 \\
& Kontrol & 37.75 & 1.75 & 37.37 & 1.68 & 38.5 & 1.30
\end{tabular}

Tablo 11 incelendiğinde, deney ve kontrol gruplarının ön-test puan ortalamalarının birbirine denk olduğu görülürken; son-test ve izleme testi puanlarında deney ve kontrol grubu arasında farklılıklar olduğu görülmektedir. Deney ve kontrol gruplarının ABBÖ'den elde ettikleri puan ortalamaları arasındaki farkın anlamlı olup olmadığı varyans analizi (ANOVA) ile test edilmiştir. Elde edilen bulgular Tablo 12'de sunulmuştur.

Tablo 12. Deney ve Kontrol Gruplarının ABBÖ Ön-test, Son-test ve İzleme Testi Puanlarına Iliş̧kin İki Faktörlü Varyans Analizi Sonuçları

\begin{tabular}{ccccccc}
\hline Kaynak & $\begin{array}{c}\text { Kareler } \\
\text { Toplamı }\end{array}$ & sd & $\begin{array}{c}\text { Kareler } \\
\text { Ortalaması }\end{array}$ & $F$ & $p$ & $\begin{array}{c}\text { Eta } \\
\text { Kare }\end{array}$ \\
\hline Gruplar arası & 649.479 & 15 & & & & \\
Grup (D//K) & 581.021 & 1 & 581.021 & 118.821 & .000 & .895 \\
Hata & 68.458 & 14 & 4.89 & & & \\
Gruplar içi & 608.011 & 16 & & & & \\
Ölçüm (ön-son- izleme) & 280.292 & 1 & 140.146 & 210.219 & .000 & .943 \\
Grup * Ölçüm & 309.042 & 1 & 154.521 & 231.781 & .000 & .762 \\
Hata & 18,677 & 14 & 28.00 & .667 & & \\
\hline
\end{tabular}

Tablo 12'de görüldüğü üzere, deney ve kontrol gruplarında bulunan bireylerin, ABBÖ ön-test, sontest ve izleme testi ölçümlerinden aldıkları puanların ortalamaları üzerinde yapılan varyans analizi sonucunda, grup etkisinin anlamlı olduğu bulunmuştur $\left(F_{(1-14)}=118,21 ; p<.01\right)$. Buna göre, deney ve kontrol gruplarının ön-test, son-test ve izleme testi ölçümleri arasında ayrım yapmaksızın, ABBÖ'den elde ettikleri puanların ortalamaları arasında anlamlı düzeyde bir fark bulunduğu söylenebilir. Grup ayrımı yapılmaksızın bireylerin, ön-test, son-test ve izleme testi ölçümlerinden elde ettikleri puanların ortalamaları arasındaki farkın da anlamlı olduğu görülmüştür $\left(F_{(2-14)}=\right.$ $210,219 p<.01)$. Bu bulgu, grup ayrımı yapılmadığında, bireylerin anne-baba beklenti düzeylerinin deneysel işleme bağlı olarak değiştiğini göstermektedir. Ayrıca bu araştırma için önemli olan ortak etkinin (grup*ölçüm etkisinin) incelenmesi sonucunda, elde edilen değerin anlamlı olduğu görülmüştür $\left(F_{(2-14)}=44,73 ; p<.01\right)$. Bu bulgu, deney ve kontrol gruplarındaki bireylerin ön-test, sontest ve izleme testi ölçümlerinde ABBÖ'den elde ettikleri puanların değiştiğini göstermektedir. Tüm bu bulgular dikkate alındığında, anne-baba beklentileri ile ilgili öne sürülen denencenin doğrulandığı söylenebilir. Gruplar arasındaki ölçümlere bağlı olarak, anlamlı farkın hangi gruplar arasında olduğunu belirlemek Tukey Testi yapılmıştır.

Tukey testi sonucuna göre, deney grubunun ABBÖ'nün ön-testinden $(X=37.87)$ elde ettikleri puanların ortalamaları ile son-test $(X=27.87)$ ve izleme testi $(X=27)$ ölçümlerinden elde edilen puanların ortalamaları arasında anlamlı bir fark bulunmaktadır (10 ve 10.87, $\mathrm{p}<.01)$. Buna karşın, kontrol grubunun ABBÖ ön-testinden $(X=37.75)$ elde ettikleri puanların ortalamaları ile son-test $(X=$ 37.37) ve izleme testi $(X=38.5)$ ölçümlerinden elde ettikleri puanların ortalamaları arasındaki fark anlamlı değildir (-.37 ve -.75). Ayrıca deney grubundaki bireylerin son-test puanları $(X=27.87)$ ile kontrol grubundaki bireylerin son-test $(X=37.27)$ puanları arasında ve deney grubundaki bireylerin izleme testi $(X=27)$ puanları ile kontrol grubundaki bireylerin izleme testi $(X=38)$ puanları arasında 
anlamlı bir farklılık (-9.5 ve -11.5; $p<.01$ ) olduğu görülmektedir. Bu durum, ESYP anne-baba beklenti düzeylerini deney grubunda azaltmada anlamlı düzeyde etkili olduğu söylenebilir.

\subsection{Ergenlerde Mantıkdışı İnançları Azaltmaya Yönelik Bulgular}

Araştırmanın dördüncü denencesi, "Ebeveyn Stresini Yönetme Programı, ergen mantıkdışı inanç düzeylerini anlamlı düzeyde azaltmada etkili olacaktır ve bu etki programın tamamlanmasından bir buçuk ay sonra yapılacak ölçümlerde de devam edecektir." şeklinde ifade edilmiştir. Deney ve kontrol gruplarında yer alan katıımcıların EMiÖ ön-test, son-test, izleme testi aritmetik ortalamaları ve standart sapmaları Tablo 13'te verilmiştir.

Tablo 13. Deney ve Kontrol Gruplarının EMiö Ön-Test, Son-Test ve İzleme Testi Puanlarına Illişkin Aritmetik Ortalama ve Standart Sapma Değerleri

\begin{tabular}{llccccccc}
\hline & & \multicolumn{2}{c}{ Ön-test } & \multicolumn{2}{c}{ Son-Test } & \multicolumn{2}{c}{ İleme-Testi } \\
& Grup & $\bar{X}$ & ss & $\bar{X}$ & ss & $\bar{X}$ & ss \\
\hline EMiÖ & Deney & 78.12 & 1.95 & 62 & 2.61 & 62.62 & 2.19 \\
& Kontrol & 78.75 & 1.90 & 78.62 & 2.26 & 81.12 & 3.09 \\
\hline
\end{tabular}

Tablo 13 incelendiğinde, deney ve kontrol gruplarının ön-test puan ortalamalarının birbirine denk olduğu görülürken; son-test, izleme testi puanlarında deney ve kontrol grubu arasında farklılıklar olduğu görülmektedir. Deney ve kontrol gruplarının EMiö'den elde ettikleri ölçüm puan ortalamaları arasındaki farkın anlamlı olup olmadığı varyans analizi (ANOVA) ile test edilmiştir. Elde edilen bulgular Tablo 14'de sunulmuştur.

Tablo 14. Deney ve Kontrol Gruplarının EMiÖ Ön-test, Son-test ve İzleme Testi Puanlarına Iliş̧kin İki Faktörlü Varyans Analizi Sonuçları

\begin{tabular}{ccccccc}
\hline Kaynak & $\begin{array}{l}\text { Kareler } \\
\text { Toplamı }\end{array}$ & sd & $\begin{array}{l}\text { Kareler } \\
\text { Ortalaması }\end{array}$ & $F$ & $p$ & $\begin{array}{l}\text { Eta } \\
\text { Kare }\end{array}$ \\
\hline Gruplar arası & 1856.583 & 15 & & & & \\
Grup (D//K) & 1704.083 & 1 & 1704.083 & 156.440 & .000 & .918 \\
Hata & 152.500 & 14 & & & & \\
Gruplar içi & 1451.334 & 16 & & & & \\
Ölçüm (ön-son- izleme) & 594.792 & 1 & 302.235 & 98.545 & .000 & .876 \\
Grup * Ölçüm & 772.042 & 1 & 392.302 & 127.912 & .000 & .901 \\
Hata & 84.500 & 14 & 3.067 & & & \\
\hline
\end{tabular}

Tablo 14'de görüldüğü üzere, deney ve kontrol gruplarında bulunan ergenlerin, EMiÖ izleme testi ölçümlerinden aldıkları puanların ortalamaları üzerinde yapılan varyans analizi sonucunda, grup etkisinin anlamlı olduğu bulunmuştur $\left(F_{(1-14)}=156,44 p<.01\right)$. Buna göre, deney ve kontrol gruplarının ön-test, son-test ve izleme testi ölçümleri arasında ayrım yapmaksızın, EMiö'den elde ettikleri puanların ortalamaları arasında anlamlı düzeyde bir fark bulunduğu söylenebilir. Grup ayrımı yapılmaksızın ergenlerin, ön-test, son-test ve izleme testi ölçümlerinden elde ettikleri puanların ortalamaları arasındaki farkın da anlamlı olduğu görülmüştür $\left(F_{(2-14)}=98,54 p<.01\right)$. Bu bulgu, grup ayrımı yapılmadığında, ergenlerin mantıkdışı inanç düzeylerinin deneysel işleme bağlı olarak değiştiğini göstermektedir. Ayrıca bu araştırma için önemli olan ortak etkinin (grup*ölçüm etkisinin) incelenmesi sonucunda, elde edilen değerin anlamlı olduğu görülmüştür $\left(F_{(2-14)}=127,91\right.$; $\mathrm{p}<.01)$. Bu bulgu, deney ve kontrol gruplarındaki ergenlerin ön-test, son-test ve izleme testi ölçümlerinde EMiÖ'den elde ettikleri puanların değiştiğini göstermektedir. Tüm bu bulgular dikkate alındığında, ergenlerdeki mantıkdışı inanç ilgili öne sürülen denencenin doğrulandığı söylenebilir. Gruplar arasındaki ölçümlere bağı olarak, anlamlı farkın hangi gruplar arasında olduğunu belirlemek Tukey Testi yapılmıştır. 
Tukey testi sonucuna göre, deney grubunun EMiÖ'nün ön-testinden $(X=78.12)$ elde ettikleri puanların ortalamaları ile son-test $(X=62)$, ve izleme testi $(X=62.62)$ ölçümlerinden elde edilen puanların ortalamaları arasında anlamlı bir fark bulunmaktadır (16.12 ve 15.50; $p<.01)$. Buna karşın, kontrol grubunun EMiö'nün ön-testinden $(X=78.75)$ elde ettikleri puanların ortalamaları ile son-test $(X=78.62)$ ve izleme testi $(X=81.12)$ ölçümlerinden elde ettikleri puanların ortalamaları arasındaki fark anlamlı değildir (.12 ve -.2.37). Ayrıca deney grubundaki bireylerin son-test puanları $(X=62)$ ile kontrol grubundaki bireylerin son-test $(X=78.62)$ puanları arasında ve deney grubundaki bireylerin izleme testi $(X=62.62)$ ile kontrol grubundaki bireylerin izleme testi $(X=81.12)$ puanları arasında anlamlı bir farklılık (-16.62 ve $-18.5 ; p<.01)$ olduğu görülmektedir. Bu sonuçlar, ESYP'nin ergen mantıkdışı inanç düzeylerini deney grubunda azaltmada anlamlı düzeyde etkili olduğunu ortaya koymaktadır.

\section{SONUÇ, TARTIŞMA VE ÖNERILER}

\subsection{Sonuçlar}

1. ESYP, ebeveynlik stres düzeylerini anlamlı derecede azaltmış ve bu azalma program bittikten bir buçuk ay sonra da devam etmiştir.

2. ESYP, ebeveyn mantıkdışı inanç düzeylerini anlamlı derecede azaltmış ve bu azalma program bittikten bir buçuk ay sonra da devam devam etmiştir.

3. ESYP, ergenlerin anne baba beklentilerine ilişkin stres düzeyleri anlamlı derecede azaltmış ve bu azalma program bittikten bir buçuk ay sonra da devam devam etmiştir.

4. ESYP, ergenlerin mantıkdışı inanç düzeylerini anlamlı derecede azaltmış ve bu azalma program bittikten bir buçuk ay sonra da devam devam etmiştir.

\subsection{Tartışma}

Illk olarak, bu çalışma sonucunda, ESYP'nin ebeveynlik stres düzeyini anlamlı derecede azalttığı ve bu azalmanın program bittikten bir buçuk ay sonra da devam ettiği saptanmıştır. Araştırmanın bağımsız değişkenini oluşturan ebeveyn stresini yönetme programı, iki yaklaşımın (bilişsel davranışçı yaklaşım ve sistemik aile terapisi) ilkeleri dikkate alınarak hazırlanmıştır. Literatürde de bu araştırmanın bulgularını destekleyen ve ebeveyn stres düzeyini azaltmada etkililiği gösterilmiş hem aile terapisi tabanlı (Kratochwill ve diğerleri, 2004; McDonald ve diğerleri, 2012; Sanders,1999) hem de bilişsel davranışçı terapi tabanlı çalışmalara (Barret ve diğerleri, 2001; 2006) rastlanmaktadır.

Literatürde ebeveynlik stres düzeyi ile ebeveynlerin akıldışı inanç düzeyleri arasında anlamlı bir ilişki olduğu ortaya konmuştur (Bugenthal ve Johnston, 2000; DiGiuseppe ve Kelter, 2006; McGillicuddy-DeLisi ve Siegel, 1995; Terjesen ve Kurasaki, 2009). Bu belirtilen ilişki dikkate alınarak ESYP'de mantıkdışı inançlara müdahale etmeye yönelik etkinliklere yer verilmiştir. Araştırmanın sonucunda ESYP'nin ebeveyn mantıkdışı inanç düzeylerini anlamlı derecede azalttığı ve bu azalmanın program bittikten bir buçuk ay sonra da devam devam ettiği gözlenmiştir. Ayrıca Çekiç ve arkadaşlarının (2016), 26 ebeveyn üzerinde yürüttükleri çalışmada, Akılcı Duygusal Aile Eğitim Programının (ADAEP), anne babaların akılcı olmayan inançlarını ve anne-babalık streslerini anlamlı düzeyde azalttığı yönünde elde ettiği bulgu da bu araştırmanın ilk iki sonucu ile paralellik göstermektedir.

Araştırmanın üçüncü bulgusu; ESYP'nin ergenlerin anne baba beklentilerine ilişkin stres düzeylerini anlamlı derecede azalttığı ve bu azalmanın program bittikten bir buçuk ay sonra da devam devam ettiğidir. Araştırmanın bu bulgusu literatürde, ebeveyne uygulanan grup programlarının hem ebeveyni hem çocuğu olumlu etkilediği yönündeki bulgular ile paralellik göstermektedir (Gravita ve Joyce, 2008; Lundahl ve diğerleri, 2003; Sanders, 2008; Sanders ve diğerleri, 2007). Araştırmanın dördüncü bulgusu ise ESYP'nin ergenlerin mantıkdışı inanç düzeylerini anlamlı derecede azalttığı ve bu azalmanın program bittikten bir buçuk ay sonra da devam devam ettiğidir. Araştırmanın bu 
bulgusu, ergenlikte mantıkdışı inançların çoğunun çocukken anne-babanın ve çevrenin bireye karşı tutumlarından veya anne-babanın sahip olduğu mantıkdışı inançlardan edinildiği görüşünü destekler niteliktedir (Azar, 1996; Sigel ve McGillicuddy-De Lisi, 2002). Ayrıca Donnelly, Renk, Sims ve McGuire (2010) yaptıkları çalışmada, annenin pozitif otomatik düşünceleri ile çocuğun pozitif otomatik düşünceleri arasında negatif düşüncelerden daha yüksek düzeyde bir ilişsi olduğunu göstermiştir. Bu durumda, ebeveynin mantıkdışı inançlarının pozitif yönde değişmesi çocuğunun mantıkdışı inançlarının pozitif yönde değişmesine olanak sağlamış olabilir.

Ayrıca erken ergenlik dönemi anne ile ergen arasındaki çatışmanın doruk noktasına ulaştı̆̆ı bir dönemdir. Bu dönemde yaşanılan stres verici her türlü günlük olay (arkadaş problemleri, okul sorunları vb) bu çatışmayı artırmakta ve ergenin sağlıksız tercihler yapmasına ve sağlıksız tutumlar sergilemesine yol açabilmektedir (Allison, 2000; Steinberg, 2001). Bu programda ele alınan konuların, özellikle ebeveynin mantıkdışı inançlarını ele alan etkinliklerin, annelerin ergen çocukları ile yaşadığı birçok sorunla başa çıkmada kullanılacak genel geçer yöntemler olduğu söylenebilir. Literatürde ebeveynin mantıkdışı inançlarını ele alan programların [Friends (Barrett ve diğerleri, 2001; Barrett ve diğerleri, 2006) diğer pek çok sorunu da ele almada etkin olduğunu ifade etmesi bu durumu desteklemektedir. Bu bağlamda ESYP, annelerin ergen çocukları ile yaşadıkları birçok sorunu daha etkili çözmeleri için faydalı bir araç olabilir.

Son olarak, ESYP'nin yapısının ve içeriğinin bilişsel davranışçı terapi ve aile terapisi tabanlı olması, programda olumsuz yaşantıların kaynaklar ve güçlü özellikler bağlamında ele alınması, programda sağlıklı başa çıkmaların üzerinde durulması, programda ev ödevlerinin olması ve programın uzmanlar tarafından gözden geçirilmesi programa katılan annelerin ebeveyn stres düzeylerini, akıldışı inançlarını, yanı sıra ergenlerin akademik beklentilere ilişkin stresini ve mantıkdışı inançlarını azaltmada etki etmiş olabilir.

\section{3 Öneriler}

Mevcut araştırmanın kısıtlılıkları göz önünde bulundurulduğunda, araştırmacı ve uygulayıcılara çeşitli önerilerde bulunulabilir. Öncelikle bu çalışmanın bulguları, sadece annelerden elde edilen verilerle sınırıdır; ancak ebeveyn olarak babanın da ergen üzerine önemli bir etkisi vardır. Bu bağlamda, çalışmadaki program her iki ebeveyn dahil edilererek test edilebilir. Ayrıca bu çalışma 6 oturumla sınırlıdır. Programın içeriği zenginleştirilip oturum sayısı artıılarak (8-12 oturum) etkililiği yeniden sınanabilir. Bunların dışında, ESYP'nin etkililiği 8. sınıf düzeyinde çocuğu olan annelerle sınırlıdır. Ileride yapılacak çalışmalarda bu program, 6. ve 7. sınıf düzeyinde çocuğa sahip ebeveynlere (anne/baba) de uygulanarak ebeveynlerin ve ergenlerin ileride yaşayabilecekleri stres önlenebilir. ESYP'nin etkililiği, akademik beklentilere ilişkin stres ile sınırıdır. ileride yapılacak olan çalışmalarda, ESYP'nin içeriği farklılaştırılarak ergenlerin yaşadığı başka sorunlar (örn. Ilişki sorunları) üzerinde de çalışılabilir. Son olarak bu araştırmada, ESYP'nin etkililiği 1,5 aylık izleme testi sonucu ile sınırlıdır. Gelecek araştırmalarda, ESYP'nin daha uzun süreli etkililiğine bakılabilir ve kalıcılığı test edilebilir. Sonuç olarak, bu araştırma kapsamında geliştirilen ESYP, psikolojik danışma ve rehberlik alanında çalışan uzmanlar tarafından kolaylıkla kullanılabilecek biçimde organize edilmiştir. Bu bağlamda uzmanlar tarafından tekrar uygulanıp test edilebilir.

\section{Kaynakça}

Aber, J. L., Jones, S. ve Cohen, J. (2000). The impact of poverty on the mental health and development of very young children. In C. H. Zeanah Jr. (Ed.), Handbook of infant mental health (2nd ed., pp. 113-128). New York, NY: Guilford Press.

Abidin, R. R. (1995). Parenting stress index third edition: Professional manual. Lutz, FL: Psychological Assessment Resources, Inc. 
Allison, B. N. (2000). Parent-adolescent conflict in early adolescence: Research and implications for middle school programs. Journal of Family and Consumer Sciences Education, 18(2), 1-6.

Ang, R. P. ve Huan, V. S. (2006). Relationship between academic stress and suicidal ideation: Testing for depression as a mediator using multiple regression. Child Psychiatry and Human Development, 37, 133-143.

Arkan B. ve Üstün, B. (2010). Ebeveyn Eğitim Programlarını Değerlendirme Rehberi. Dokuz Eylül Üniversitesi Hemşirelik Yüksekokulu Elektronik Dergisi, 3(2), 102-107.

Ayyash-Abdo, H. (2002). Adolescent suicide: an ecological approach. Psychology in Schools, 39, 459475.

Azar, S. T. (1996). Cognitive restructuring of professionals' schema regarding women parenting in poverty. Women and Therapy, 18, 149-163.

Azar, S. T., Reitz, E. B. ve Goslin, M. C. (2008). Mothering: Thinking is part of the job description: Application of cognitive views to understanding maladaptive parenting and doing intervention and prevention work. Journal of Applied Developmental Psychology, 29, 295-304.

Balcı, A. (1997). Sosyal Bilimlerde Araştırma: Yöntem, Teknik ve ilkeler, Ankara: TDFO Yayınları.

Barmish, A. J. ve Kendall, P.C. (2005). Should parents be co-clients in cognitive-behavioral therapy for anxious youth? Journal of Clinical Child and Adolescent. Psychology, 34, 569-581.

Barrett, P. M., Farrell, L. J., Ollendick, T. H. ve Dadds, M. (2006). Long-term outcomes of an Australian universal prevention trial of anxiety and depression symptoms in children and youth: An evaluation of the friends program. Journal of Clinical Child and Adolescent Psychology, 35, 403-411.

Barrett, P. M. ve Pahl, K. M. (2006). School-based intervention: Examining a universalapproach to anxiety management. Australian Journal of Guidance and Counselling, 16, 55-75.

Barrett, P. M., Shortt, A. L., Fox, T. L. ve Wescombe, K. (2001). Examining the social validity of the friends treatment program for anxious children. Behaviour Change, 18, 63-77.

Bernard, M. E. (2003). Investing in parents: what parents need to know and do to support their children's achievement and social-emotional well-being. Laguna Beach, CA: You Can Do It! Education.

Boyacıoğlu, N. E. (2010). Ergenlerde mantık dışı inançlar ve sınav kaygısı. (Yayımlanmamış yüksek lisans tezi)., İstanbul Üniversitesi, Sağlık Bilimleri Enstitüsü.

Boyacıoğlu, N. E. ve Küçük, L. (2011). Ergenlikte mantık dışı inançlar sınav kaygısını nasıl etkiliyor? Psikiyatri Hemşireliği Dergisi; 2(1), 40-45.

Bugental, D. B. ve Johnston, C. (2000). Parental and child cognitions in the context of them family. Annual Review of Psychology, 51, 315-344.

Büyüköztürk, Ş. (2002). Deneysel Desenler Öntest-Sontest Kontrol Gruplu Desen ve Veri Analizi. Ankara: Pegem A Yayıncılık.

Capaldi, D., DeGarmo, D., Patterson, G. R. ve Forgatch, M. (2002). Contextual risk across early life span and association with antisocial behavior. In J. Reid, J. R. Patterson ve J. Snyder (Eds.) Antisocial behavior in children and adolescents: A developmental analysis and model for intervention (pp. 123-145). Washington, DC: American Psychological Association.

Cornell, D. G., Krosnick, J. A. ve Chang, L. (2006). Student reactions to being wrongly informed of failing a high-stakes test: The case of the Minnesota Basic Standards Test. Educational Policy, 20, 718-751.

Creasey, G. ve Reese, M. (1996). Mothers' and fathers' perceptions of parenting hassles: Associations with psychological symptoms, nonparenting hassles, and child behavior problems. Journal of Applied Developmental Psychology, 17, 393-406.

Çelik, Z. (2006). ilköğretim öğrencilerinin başarı güdüleri ve ana baba beklentilerine ilişkin algıları. (Yayımlanmamış yüksek lisans tezi). Dokuz Eylül Üniversitesi, Eğitim Bilimleri Enstitüsü, İzmir. 
Çekiç, A., Akbaş, T. ve Hamamcl, Z. (2015). Anne Baba Stres Ölçeği'nin Türkçe' ye Uyarlaması: Geçerlik ve Güvenirlik Çalışması1 Adaptation of Parenting Stress Index into Turkish: Gaziantep University Journal of Social Sciences, 14(3), 647-667.

Çekiç, A., Akbaş, T. ve Hamamcı, Z. (2016). Akılcı duygusal aile eğitim programının anne babaların akılcı olmayan inançlarına ve anne babalık streslerine etkisi. International Journal of Human Science, 13(1), 2398- 2417.

Çivitci, A. (2006). Ergenler için mantıkdışı inançlar ölçe inin geliştirilmesi: Geçerlik ve güvenirlik çalışması. Türk Psikolojik Danışma ve Rehberlik Dergisi, 3(25), 69-80.

Çivitci, A. (2007). Erken ergenlik döneminde içsel-dışsal denetim odağı boyutları ve cinsiyete göre mantıkdışı inançlar. Çocuk ve Gençlik Ruh Sağlığı Dergisi, 14(1), 3-12.

Daymaz, S. (2012). Ilköğretim 7.sınıf öğrencilerinin anne baba beklentileri ile sınav kaygısı arasındaki ilişkinin incelenmesi (Istanbul ili tuzla ilçesi örneği) (Yayımlanmamış yüksek lisans tezi). Yeditepe Üniversitesi, İstanbul.

Deater-Deckard, K. (1998). Parenting stress and child adjustment: Some old hypotheses and new questions. Clinical Psychology: Science and Practice, 5, 314-332.

Deater-Deckard, K. (2004). Parenting Stress. Yale University Press. New Haven and London.

DeGarmo, D. S., Patterson, G. R. ve Forgatch, M. S. (2004). How do outcomes in a specified parent training intervention maintain or wane over time? Prevention Science, 5, 72-89.

Denscombe, M. (2000). Social conditions for stress: Young people's experience of doing GCSEs. British Educational Research Journal, 26, 359-374.

DiGiuseppe, R. ve Kelter, J. (2006). Treating aggressive children: A rational-emotive behavior systems approach. In, A. Ellis ve M. E., Bernard. Rational Emotive Behavioral Approaches to Childhood Disorders. Theory, Practice and Research (pp.257-280), New York, NY: Springer.

Donnelly, R., Renk, K., Sims, V. ve McGuire, J. (2011). The relationship of parent and child self-talk in a college sample. Child Psychiatry and Human Development, 42, 197-218.

Duncan, G. ve Brooks-Gunn, J. (2000). Family poverty, welfare reform, and child development. Child Development, 71(1), 188-196.

Eryüksel, G. N. ve Argün, E. (2003). Depresyonu olan Ergenler ile Anne Babaların Aile iliş̧kilerinin ve Bilişsel Çarpıtmalarının İncelenmesi. Türk Psikoloji Dergisi, 18 (51), 59-73.

Fisher, R. L. (2003). School-based family support: Evidence from an exploratory field study. Families in Society, 84, 339-347.

Frome, P. M. ve Eccles, J. S. (1998). Parents' influence on children's achievement-related perceptions. Journal of Personality and Social Psychology, 74(2), 435-452.

Gavita, O. ve Joyce, M. (2008). A review of the effectiveness of group cognitively enhanced behavioral based parent programs designed for reducing disruptive behavior in children. Journal of Cognitive and Behavioral Psychotherapies, 8, 185-199.

Gloria, A. M. ve Ho, T. A. (2003). Environmental, social, and psychological experiences of Asian American undergraduates: Examining issues of academic persistence. Journal of Counseling and Development, 81, 93-105.

Görmez, M. ve Coşkun, ì. (2015). 1. Yılında temel eğitimden ortaöğretime geçiş reformunun değerlendirilmesi. Siyaset, Ekonomi ve Toplum Araştırmaları Vakfı, 114, 7-22.

Joyce, M. R. (1995). Emotional relief for parents: Is rational-emotive parent education effective. Journal of Rational-Emotive and Cognitive-Behavior Therapy, 13(1), 55-75.

Joyce, M. (2006). Rational-emotive behavioral approaches to childhood disorders: History, theory, practice, and research. In A. Ellis ve M. E. Bernard (Eds.), Rational emotive behavior approaches to childhood disorders. New York: Springer.

Kaplan, D. S., Liu, X. ve Kaplan, H. B. (2001). Influence of parents' self-feelings and expectations on children's academic performance. Journal of Educational Research, 94, 360-370. 
Kaya, i. ve Hamamci, Z. (2013). Parent irrational beliefs scale: Reliability and validity on parents with secondary schools children. Eğitimde Kuram ve Uygulama, 9(4), 408-420.

Kelecioğlu, H. ve Bilge, F. (2009). Akademik Beklentilere IIlişkin Stres Envanteri'nin Uyarlanması: Geçerlik ve Güvenirlik Çalışmaları. Hacettepe Üniversitesi Eğitim Fakültesi Dergisi, 36, 148-15.

Kesici, A. ve Aşılıoğlu, B. (2017). Ortaokul Öğrencilerinin Matematiğe Yönelik Duyuşsal Özellikleri Ile Temel Eğitimden Ortaöğretime Geçiş (Teog) Sınavları Öncesi Yaşadıkları Stresin Matematik Başarısına Etkisi. Ahi Evran Üniversitesi Kırşehir Eğitim Fakültesi Dergisi, 18(3), 395-414.

Koeske, G. ve Koeske R. (1990). The buffering effect of social support on parental stress. American Journal of Orthopsychiatry, 60, 440-451.

Kratochwill, T. R., McDonald, L., Levin, J. R., Bear-Tibbetts, H. Y. ve Demaray, M. K. (2004). Families and schools together: An experimental analysis of a parent-mediated multi-family group program for American Indian children. Journal of School Psychology, 42, 359-383.

Kruger, L. J., Wandle, C. ve Struzzierro, J. (2007). Coping with the stress of high stakes testing. Journal of Applied School Psychology, 23(2), 109-128.

Liddle, H. A. ve Hogue, A. (2000). A family-based, developmental-ecological preventiveintervention for high-risk adolescents. Journal of Marital and Family Therapy, 26, 265-279.

Liddle, H. A., Singer, A. ve Leckrone, J. (2005). Intervention fidelity in family-based prevention counseling for adolescent problem behaviors. Journal of Community Pychology, 33(2), 1919-211.

Lock, S. ve Barrett, P. M. (2003). A longitudinal study of developmental differences in universal preventive intervention for child anxiety. Behaviour Change, 20, 1183-1199.

Lowry-Webster, H., Barrett, P. M. ve Dadds, M. R. (2001). A universal prevention trial of anxiety and depressive symptomatology in childhood: Preliminary data from an Australian study. Behaviour Change, 18, 36-50.

Lundahl, B., Risser, H. J. ve Lovejoy, M. C. (2006). A meta-analysis of parent training: Moderators and follow-up effects. Clinical Psychology Review, 26, 86-104.

McDonald, A. (2001). The prevalence and effects of test anxiety in school children. Educational Psychology, 21(1), 89-101.

McDonald, L., FitzRoy, S. Fuchs, I., Fooken I. ve Klasen, H. (2012) Strategies for high retention rates of low-income families in FAST (Families and Schools Together): An evidence-based parenting programme in the USA, UK, Holland and Germany, European Journal of Developmental Psychology, 9(1), 75-88.

MEB. (2015). sgb.meb.gov.tr/istatistik/meb_istatistikleri_orgun_egitim_2014_2015.pdf adresinden 30.03.2018 tarihinde alınmıştır

Morgan, J., Robinson, D. ve Aldridge, J. (2002). Parenting stress and externalizing child behavior. Child and Family Social Work, 7, 219-22.

Moulds, J. D. (2003). Stress manifestation in high school students: An Australian sample. Psychology in the Schools, 40(4) 391-402.

Östberg, M., Hagekull, B. ve Wettergren, S. (1997). A measure of parental stress in mothers with small children: dimensionality, stability and validity. Scandinavian Journal of Psychology, 38, 199208.

Östberg, M. ve Hagekull, B. (2000). A structural modeling approach to the understanding of parenting stress, Journal of Clinical Child Psychology, 29(4), 615-625.

Özmen-Kaymak, S. ve Özmen, A. (2012). Anne baba stres ölçeğinin geliştirilmesi. Eğitim ve Sosyal Bilimler Dergisi, 41(196), 20-34.

Pearson, V. ve Chan, T. W. L. (1993). The relationship between parenting stress and social support in mothers of children with learning disabilities: A Chinese experience. Social Science and Medicine, 37(2), 1993, 267-274. 
Putwain, D. W., Connors, L. ve Symes, W., (2010). Do cognitive distortions mediate the test anxietyexamination performance relationship? Educational Psychology, 30(1), 11-26.

Ross, S. E., Niebling, B. C. ve Heckert, T. M. (1999). Sources of stress among students. College Student Journal, 33(2), 312-317.

Sanders, M. R. (1999). Triple P-positive parenting program: Towards an empirically validated multilevel parenting and family support strategy for the prevention of behavior and emotional problems in children. Clinical Child and Family Psychology Review, 2(2), 71-90.

Sanders, M. R, Bor, W. ve Morawska, A. (2007). Maintenance of treatment gains: a comparison of enhanced, standard, and self-directed Triple P-Positive Parenting Program. Journal of Abnormal Child Psychology, 35, 983-998.

Sigel, I. E. ve McGillicuddy-De Lisi, A. V. (2002). Parent beliefs are cognitions: The dynamic belief systems model. In M. Bornstein (Ed.), Handbook of parenting Vol. 3: Being and becoming a parent (pp. 485-508). Hillsdale, NJ: Erlbaum.

Steinberg, L. (2001). We know some things: Adolescent-parent relationships in retrospect and prospect. Journal of Research on Adolescence, 11, 1-20.

Şad, S. N. ve Şahiner, Y.K. (2016). Temel Eğitimden Ortaöğretime Geçiş (TEOG) Sistemine iliş̧kin Öğrenci, Öğretmen ve Veli Görüşleri. Elementary Education Online 15(1), 53-76.

Tan, J. B. ve Yates, S. (2011). Academic expectations as sources of stress in Asian students. Social Psychology of Education, 14, 389- 407.

Terjesen, M. D. ve Kurasaki, R. (2009). Rational emotive behavior therapy: Applications for working with parents and teachers. Estudos de Psicologia Campinas, 26(1), 3-14.

The Conduct Problems Prevention Research Group1. (2002). The implementation of the fast track program: An example of a large-scale prevention science efficacy trial. Journal of Abnormal Child Psychology, 30(1), 1-17.

Ulusoy, M. A., Pan, V. L., Turan, M. O, Başken, B. ve Akbulut, A. (2016). Türk milli eğitim sistemindeki reform hareketlerinin öğrencilerin sınav kaygısı üzerine etkisi, VIII. Uluslararası Eğitim Araştırmaları Kongresi, 769-778.

Yerlikaya, í. (2014). Devlet ve özel ortaokul öğrencilerinin umutsuzluk düzeyinin belirlenmesi ve çeşitli değişkenlerle incelenmesi. Turkish Studies, 9(8), 865-877.

Yıldırım, D. (2004). Depresyonun yordayıcısı olarak sınav kaygısı, gündelik sıkıntılar ve sosyal destek. Hacettepe Üniversitesi Eğitim Fakültesi Dergisi, 27, 241-250.

Zayimoglu-Öztürk, F. ve Aksoy, H. (2014). Temel Eğitimden Ortaöğretime Geçiş Modelinin 8. Sınıf Öğrenci Görüşlerine Göre Değerlendirilmesi (Ordu ili Örneği). OMÜ Eğitim Fakültesi Dergisi, 33(2), 439-454.

Zeytin, Y. (2015). Üniversite giriş sınavlarına hazırlanan öğrencilerin akademik beklentilere ilişkin stres ve öznel iyi oluş düzeylerinin incelenmesi, (Yayımlanmamış yüksek lisans tezi). Gaziantep Üniversitesi, Eğitim Bilimleri Enstitüsü, Gaziantep. 


\section{Extended Summary}

\section{Introduction}

The concept of "parent stress" implies the type of stress that parents experience when they believe that they cannot meet the role of being mother and father brings along (Abidin, 1995, DeaterDeckard, 1998). Parents with low social status and limited resources, especially in Asian countries, including Turkey, are more worried about the future, so they regard academic career as the only option (Gurland and Grolnick, 2005; Tan ve Yates, 2011). In this sense, families with low socioeconomic status can expect academic success that they cannot do themselves from their adolescent children and lead to increase in academic stress of their children (Moulds, 2003; Yıldırım, 2004). Students preparing for important exams and failing important exams are at risk for psychological problems (Cornell et. al., 2006; Denscombe, 2000). In this context, the 8th grade that is a preparation period for the transition exam from primary education level to the secondary education level (TEOG) is a risky period for the parents and the adolescents with lowsocioeconomic status (Yerlikaya, 2014). In every year, 1.-1.5 million students preparing for TEOG examination are at risk. Adolescents'stress related to academic expectations stems from the irrational beliefs that cause to interpret events negatively while trying to cope with the academic stress (Putwain et. al., 2010). Adolescents obtain most of their irrational beliefs from their parents' irrational beliefs (Azar, 1996; Sigel ve McGillicuddy-De Lisi, 2002). In this sense, intervention programs implemented to parents (Capaldi et.al., 2002; DeGarmo et.al., 2004) affect both parents and adolescents positively.

In the international literature, there are studies examining parent stress and irrational beliefs based on Systemic Family Therapy (The Triple P-Positive Parenting Program: Sanders, 1999; FAST: Kratochwill et. al., 2004; McDonald et. al., 2012) and Cognitive Behavioral Therapy (FRIENDS: Barrett et.al., 2006) in the clinical and theoretical context. In the national literature, there are descriptive studies investigating parenting stress (Çekiç et. al., 2015; Özmen ve Özmen, 2012), parents' irrational beliefs (Eryüksel ve Agün, 2003; Kaya ve Hamamcl, 2011), adolescents' stress level that is related to academic expectations (Çelik, 2006; Keçelioğlu ve Bilge, 2008) and irrational beliefs of adolescents (Boyacıoğlu ve Küçük, 2011; Çivitçi, 2006, Güler, 2012). Besides, there is only one study examining parent stress and irrational beliefs experimentally (Çekiç, et al. 2016). However, any experimental study which addresses parenting stress that is a predictor of clinical problems, irrational beliefs of parents and adolescents, and adolescents' stress that is related to academic expectations is not found. Therefore, this quasi experimental research investigates the effectiveness of "Parent Stress Management Program (PSMP)" on parent stress level of mothers, parent irrational beliefs level of mothers and on parent expectation level of adolescents and irrational beliefs level of adolescents preparing for TEOG exam

\section{Method}

Parent Stress Scale (Kaymak-Özmen ve Özmen, 2012), Parent Irrational Belief Scale (Kaya ve HamamcI, 2011); Parent Expectation Scale (Çelik, 2006) and Irrational Beliefs Scale for Adolescents (Çivitçi, 2006a) were utilized. In the study 16 mother and 16 adolescent from 124 mother and 124 adolescent were selected according to their above a half standard deviation. In experimental group only 8 mothers were taken. A six session Parent Stress Management Program (PSMP) was applied to mothers in the experimental group. Any intervention was not applied in the control group. After the application of the (PSMP) in the experimental group post-tests were given to mothers and adolescents both in the experimental group and control group to determine the effectiveness of (PSMP). Follow-up test was given to both groups six weeks after post-test to determine the permanent effect of the program. In the analysis, parametric method was met $2 \times 3$ two-way repeated measures of ANOVA were used. To identify the source of significant differences in observed cases Tukey (HSD) was analyzed $(p<.05)$ 


\section{Results}

For mothers: Parent stress management program was significantly more effective in decreasing the parent stress levels and parent irrational beliefs in the experiment group than the control group and this effect was sustained in measurements to be conducted one and a half month following the completion of the program.

For adolescents: Parent stress management program was significantly more effective in decreasing the parent expectation levels and the irrational beliefs in the experiment group than the control group and this effect will be sustained in measurements to be conducted one and a half month following the completion of the program

\section{Discussion and Conclusion}

The first results of the research showed that Parent Stress Management Program have been effective in decreasing parent stress. This program as the independent variant of the research was prepared on the basis of two principles (cognitive behavioral therapy approach, and systemic family therapy). In literature there are some cognitive behavioral therapy (Barrett, et al., 2006; Port, et al., 2001) and systematic family therapy studies (Kratochwill, et al., 2004; McDonald, et al., 2012) supported this mentioned above result. In literature, the relationship between parent stress and parent irrational beliefs is stated (DiGiuseppe ve Kelter, 2006; Terjesen ve Kurasaki, 2009). Thus the program and the activities of program were designed according to this statement. And the second results of the research showed that Parent Stress Management Program have been effective in decreasing parent irrational beliefs. The third results of the study showed that Parent Stress Management Program have been effective in decreasing parent expectation stress of adolescents. This result is coherent with the findings that the group programs applied to the parents positively affect both the parents and the children (Gravita ve Joyce, 2008; Lundahl et al., 2003; Sanders, 2008). The fourth results of the study Parent Stress Management Program have been effective in decreasing irrational beliefs of adolescents. In literature the relationship between parent irrational beliefs and adolescents irrational beliefs is stated (Azar, 1996; Sigel ve McGillicuddy-De Lisi, 2002). Therefore, any positive change in parental irrational beliefs may affect the child's irrational in the positive direction. The effectiveness of the program to manage parental stress is limited to the mothers at the 8th grade level. However, in future studies, this program can be implemented with parents with children at 6th and 7th grade levels, so stress that parents and adolescents may experience can be prevented earlier. Also, this program can be revised and tested with other problems (eg. relationship problems) that adolescents may have. 